\title{
A CLUTCH SIZE OF BLACK-WINGED KITE ELANUSCAERULEUS OF THE ARID ZONE OF RAJASTHAN
}

\author{
Madan Lal Meghwal ${ }^{1}$, K. C. Soni ${ }^{2}$ and V.C.Soni ${ }^{3}$ \\ ${ }^{1}$ Research Scholar, Maharaja Ganga Singh University, Bikaner, Rajasthan, India. \\ ${ }^{2}$ Department of Zoology, Lohia P. G. College, Churu (Rajasthan) 331001, India. \\ ${ }^{3}$ Department of Biosciences, Saurashtra University, Rajkot - 360005, India \\ Corresponding Email: madankhardia99@gmail.com,kcsibis@yahoo.com, \\ vcsoni2009@gmail.com
}

\begin{abstract}
The Black-winged kite (Elanuscaeruleus) is very common throughout India with wide distribution and a solitary breeder.It belongs to a family: Accipitridae. Surprisingly, no systematic studies have yet been carried out on any aspects of breeding biology of the species.Breeding of Black-winged kite poorly known [1][7].
\end{abstract}

Keyword: clutch, black-winged, kite, elanuscaeruleu, arid zone

\section{INTRODUCTION}

Among other species breeding chronology has been studied in birds such as Black eared kite (Milvus migranslineatus) by Bhuiyan and Khan [2], Brahminy kite (Haliasturindus) by Kumar [10] and Bald eagle (Haliaeetusleucocephalus) by Broley[3]. Clutch size in birds varies from species to species $[8,11,14]$. Some species lay single egg and others many more. Here, the clutch size of the Black-winged kite of arid zone of Rajasthan is given.The study was carried out during 2012 to 2014.The clutch size in the Black-winged kite varies from 2 to 3 eggs. Thirteen clutches of eggs of the species were recorded.The clutch size varies from 2 to 3 eggs per nest and the mean clutch size for the three years was 2.6 eggs per clutch. The geographical variations in the species also have been recorded by some workers. An average clutch of three or four eggs laid at Bharatpur was 3 eggs laid at 48-hour intervals [15]In Zambia clutch size ranged from 2 to 6 eggs [5]. In China, it ranged 3-4 eggs whereas in Malay Peninsula clutch size is 3 eggs [18].

Thes tudy was carried out during January 2012 to December 2014 in the rural areas of Churu city and Ratangarh 
city(Churu district) of Rajasthan, India (Lat $29^{\circ} \mathrm{N}$, Long $75^{\circ} \mathrm{E}$ and $\left.286 \mathrm{Msl}\right)$.

\section{METHODOLOGY}

For field observations Olympus binoculars 10X50 were used and for photography Nikon P510 camera with 40X zoom. Close observations of five nests were made using machan to record the clutch size. The diameter was measured using plastic vernier calipers.

\section{RESULTS}

A Black-winged kite lays an average 2.6(Table 1). The clutch size varies from 2 to 3 eggs per nest (Fig:1). Eggs of the Blackwinged kite were short elliptical in shape, glossless creamy white, heavily splashed all over with shades of brown to chocolate spots (Fig:1). The average diameter of 13 eggs studied was 39.48 X $29.9 \mathrm{~mm}$. The average weight of egg was $38.8 \mathrm{~g}$ (Table: 1). The incubation started after cluch completion. The average of hatching success was $2.2(84.6 \%)$ and average of fledgling success was $1.8(81.8 \%)$. Infertile eggs were aslo laid.19,20 and 16 nest respectively were observed at various nesting sites ranging from 2012 to 14 (Table: 2). Total annual rainfall in 2012 to 2014 were 430.2, 449.5 and 398.4 respectively (Table: 3 ).

\section{DISCUSSION}

Five nests and thirteen eggs of the Black-winged kite were recorded in rural areas of Ratangarh city (Churu district) of Rajasthan and it was observed that the clutch size comprised of two to three eggs. The mean clutch size for the three years 2012 to 2014 was 2.6 eggs per clutch. Geographical variations in clutch size have been reported in several Central American birds $[16,17]$ and in equatorial and tropical birds of prey [4]. Nest success in the Blackwinged kite affected by the clutch size like another raptor [12]. Infertile eggs are also laid by the Black-winged kite. Pesticides and biocides are being used in the surrounding agriculture fields. This species is a top consumer of food chain, so biomagnifications is also possible and may affect their reproduction. Broley[3] noticed that between 1939 and 1947 the number of productive nests of Bald eagles (Haliaeetusleucocephalus) declined significantly in Florida and that the few nests that produced chicks average fewer nestling. He found only one productive nest and it contained only single chick. DDT in female's body distributed the shell making process and causing to produce very weak shells or no shells at all. Reproductive 


\section{SDES-International Journal of Interdisciplinary Research \\ (Peer Reviewed Refereed Journal) \\ Crossref DOI: 10.47997/SDES-IJIR/1.2.2020.29-82 \\ https://shreedadueducational.com/journal

performance depended on food material has been reported in many species of Raptor $[6,9,13]$. Scarcity of food during drought may be the reason of reduced reproduction performance. Not a single nest seen on many nesting sites of black-winged kite in the year having low rainfall. Lowest rainfall in the year 2014 due to which the lowest 16 nest observed this year perhaps due to food scarcity.

Annual fluctuations in the average clutch size on account of scarcity of food. The factors affecting the number of chick, fledged were food availability and climatic factors like sand storms rainfall with ice crackers, predation by cats and human disturbance. (Figure: 2,3).

\section{CONCLUSION}

We found that the smallest clutch size of Black-winged kite was 2 eggs per clutch and largest was 3 eggs per clutch during our study. Maximum number of clutch was 3 eggs per clutch so the average clutch size was 2.6. Annual fluctuations in the clutch size depends on the uses of pesticides in agricultural fields, climatic factors and scarcity of food.

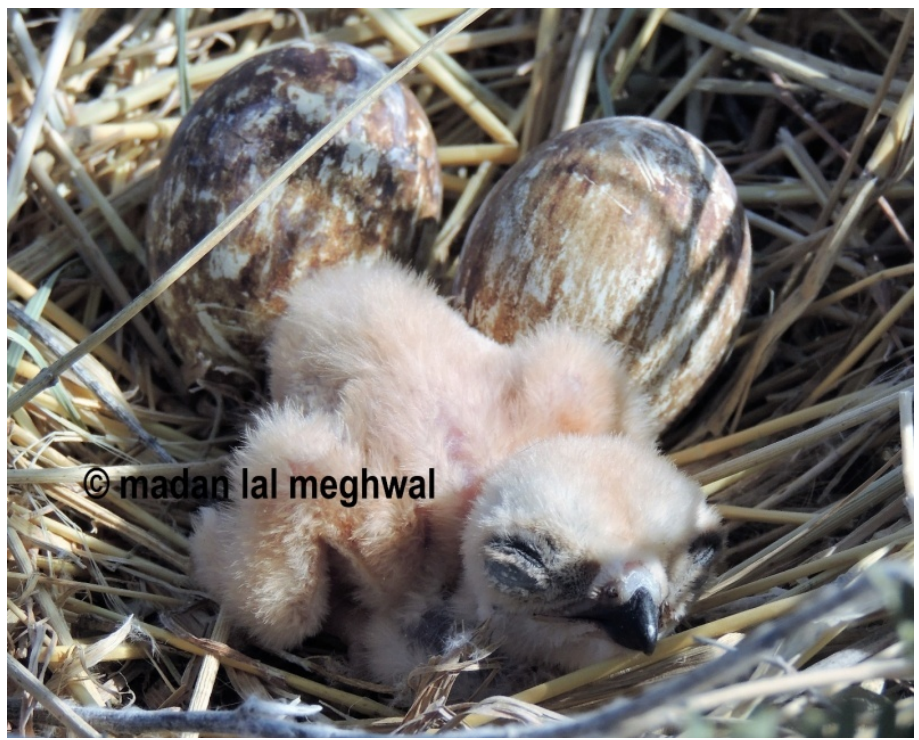

Figure: 1.A nest of Black-winged kite with two eggs and one nestling in the study area.

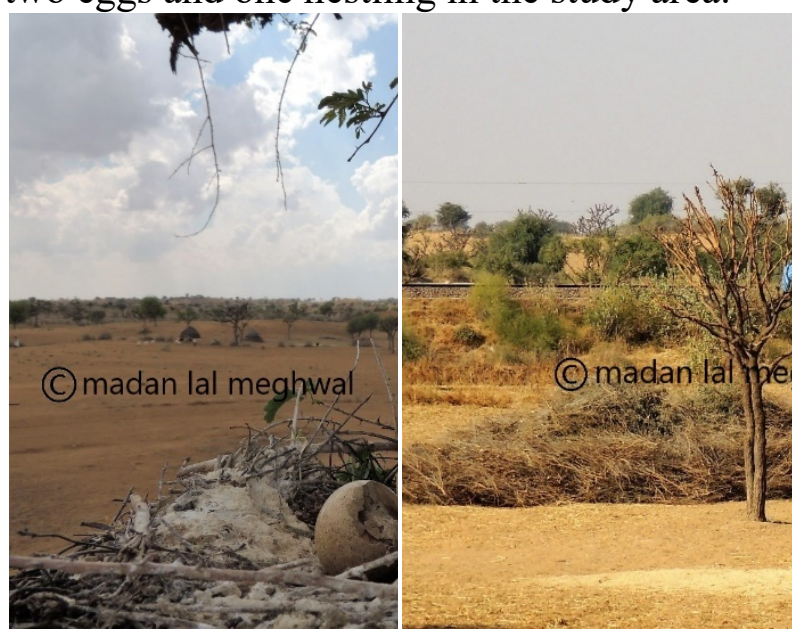

Figure: 2. Picture is Figure:3.

showing damaged Khejari(Prosopis egg of Black-winged cineraria) tree leaves kite by ice cracker and twigs are cut and during the rain. used as fodder and firewood by human beings and there by destroying the nest of Black-winged kite. 
SDES-International Journal of Interdisciplinary Research

(Peer Reviewed Refereed Journal)

Crossref DOI: 10.47997/SDES-IJIR/1.2.2020.29-82

ISSN (O): 2582:7162

https://shreedadueducational.com/journal

Table 1: Clutch Size and breeding success

of the Black-winged kite during 2012-

2014 breeding season in rural area of

Churu district (Rajasthan).

\begin{tabular}{|c|c|c|c|c|c|c|c|}
\hline $\begin{array}{c}\text { No. } \\
\text { of } \\
\text { nests }\end{array}$ & $\begin{array}{c}\text { Clut } \\
\text { ch } \\
\text { size }\end{array}$ & $\begin{array}{l}\text { Egg } \\
\text { leng } \\
\text { th } \\
(\mathrm{m} \\
\mathrm{m})\end{array}$ & $\begin{array}{l}\text { Egg } \\
\text { wid } \\
\text { th } \\
\text { (m } \\
\text { m) }\end{array}$ & $\begin{array}{c}\text { Egg } \\
\text { weig } \\
\text { ht } \\
\text { (gm) }\end{array}$ & $\begin{array}{c}\text { No. } \\
\text { of } \\
\text { infert } \\
\text { ile } \\
\text { egg }\end{array}$ & $\begin{array}{c}\text { Hatch } \\
\text { ing } \\
\text { succes } \\
\text { s }\end{array}$ & $\begin{array}{l}\text { Fledgl } \\
\text { ing } \\
\text { succes } \\
\mathrm{s}\end{array}$ \\
\hline 1 & 3 & 38.7 & 28.9 & 37.2 & Nil & 3 & 3 \\
\hline 2 & 3 & 39.1 & 29.3 & 38.7 & 01 & 3 & 2 \\
\hline 3 & 2 & 39.6 & 29.9 & 38.9 & 01 & 1 & 1 \\
\hline 4 & 2 & 39.8 & 30.2 & 39.2 & Nil & 2 & 2 \\
\hline 5 & 3 & 40.2 & 31.2 & 40.0 & Nil & 2 & 1 \\
\hline $\begin{array}{c}\text { Aver } \\
\text { age }\end{array}$ & 2.6 & $\begin{array}{c}39.4 \\
8\end{array}$ & 29.9 & 38.8 & & $\begin{array}{c}2.2 \\
(84.6 \\
\%)\end{array}$ & $\begin{array}{c}1.8 \\
(81.8 \\
\%)\end{array}$ \\
\hline
\end{tabular}

Table: 2. Number of nests in breeding season from 2012-2014.

\begin{tabular}{|l|l|c|c|c|c|}
\hline S.No. & \multicolumn{1}{|c|}{ Nesting site } & $\begin{array}{c}\text { Nesting } \\
\text { tree }\end{array}$ & $\mathbf{2 0 1 2}$ & $\mathbf{2 0 1 3}$ & $\mathbf{2 0 1 4}$ \\
\hline 1 & Shri Ganesh Temple & Khejari & 1 & 1 & Nil \\
\hline $\mathbf{2}$ & Govt. Sec. School & Khejari & 1 & 1 & 1 \\
\hline $\mathbf{3}$ & $\begin{array}{l}\text { Sukha Ram's } \\
\text { Farm }\end{array}$ & Khejari & 1 & 1 & 1 \\
\hline $\mathbf{4}$ & SurjanaJohara & Khejari & 1 & 1 & 1 \\
\hline $\mathbf{5}$ & $\begin{array}{l}\text { Lalani Johara } \\
\text { (Railway Puliya) }\end{array}$ & Khejari & 1 & 1 & 1 \\
\hline 6 & Joranath ji Temple & Khejari & Nil & 1 & 1 \\
\hline $\mathbf{7}$ & RananaJohara & Khejari & 1 & 1 & 1 \\
\hline $\mathbf{8}$ & $\begin{array}{l}\text { Mohan Ram's } \\
\text { Farm }\end{array}$ & Khejari & 1 & 1 & 1 \\
\hline 9 & $\begin{array}{l}\text { Kolath (Hanif's } \\
\text { farm) }\end{array}$ & Khejari & 1 & 1 & Nil \\
\hline $\mathbf{1 0}$ & NiraniJohara & Khejari & 1 & 1 & 1 \\
\hline 11 & $\begin{array}{l}\text { Sukra Nath Ji Ki } \\
\text { Bari }\end{array}$ & Khejari & 1 & 1 & 1 \\
\hline 12 & $\begin{array}{l}\text { Govt. Primary } \\
\text { School }\end{array}$ & Khejari & 1 & 1 & Nil \\
\hline $\mathbf{1 3}$ & CJRM School & Khejari & 1 & 1 & 1 \\
\hline 14 & Sohan Ram's farm & Khejari & 1 & 1 & 1 \\
\hline 15 & Karni Mata Temple & Khejari & 1 & 1 & 1 \\
\hline 16 & Muslim Graveyard & Khejari & Nil & 1 & 1 \\
\hline $\mathbf{1 7}$ & Choudhary Farm & Khejari & 1 & 1 & 1 \\
\hline 18 & Thakrana & Khejari & 1 & Nil & 1 \\
\hline 19 & $\begin{array}{l}\text { Primary School, } \\
\text { Mata Mandir }\end{array}$ & Khejari & 1 & 1 & Nil \\
\hline 20 & Jambhoji Gaushala & Khejari & 1 & Nil & Nil \\
\hline $\mathbf{2 1}$ & Nath Ji Ki Jhopri & Khejari & 1 & 1 & 1 \\
\hline 22 & Hanuman's Farm & Khejari & Nil & 1 & Nil \\
\hline & Total Nest build & $\mathbf{2 0}$ & $\mathbf{1 6}$ \\
\hline
\end{tabular}


Table.3. Monthly rainfall in $\mathrm{mm}$ in Churu from Jan.2012 to Dec.2014

\begin{tabular}{|l|l|l|l|}
\hline $\begin{array}{l}\text { Year } \\
\text { Month }\end{array}$ & $\mathbf{2 0 1 2}$ & $\mathbf{2 0 1 3}$ & $\mathbf{2 0 1 4}$ \\
\hline January & 0.00 & 35.70 & 17.70 \\
\hline February & 0.00 & 39.10 & 30.10 \\
\hline March & 0.00 & 0.80 & 26.30 \\
\hline April & 20.60 & 4.70 & 12.20 \\
\hline May & 29.70 & 2.20 & 87.50 \\
\hline June & 0.20 & 21.50 & 40.60 \\
\hline July & 107.00 & 183.10 & 45.70 \\
\hline August & 223.50 & 84.60 & 72.60 \\
\hline September & 38.90 & 56.30 & 65.60 \\
\hline October & 1.10 & 6.50 & 0.10 \\
\hline November & 0.00 & 15.00 & 0.00 \\
\hline December & 9.20 & 0.00 & 0.00 \\
\hline Total & 430.20 & 449.50 & 398.40 \\
\hline
\end{tabular}

\section{REFRENCES}

1. Ali, S, \&Ripley, S.D., 1978.Handbook of the Birds of India and Pakistan together with those of Bangladesh, Nepal, Bhutan and Sri Lanka, $2^{\text {nd }}$ ed. Vol. 1 Oxford University Press, Delhi.

2. Bhuiyan, H.R. \& Khan, M.A.R., 1981.Population and breeding activities of Pariah Kite Milvus migrans (Boddaert) in Greater Dacca, Bangladesh. Proc. Third National Zoological Conference, Dacca.; 266281.
3. Broley, C.L., 1947.Migration and nesting of Florida Bald Eagles, Haliaeetusleucocephalus.

Wilson Bull.59(1): 1-68.

4. Brown, L.H. \&Amadon, D., 1968.Eagles, Hawks and Falcons of the World. Vol. I \& II. Country Life Books, London.

5. Dowsett, R.J., Aspinwall, D.R. \&Dowsett-Lemaire, F., 2008. The birds of Zambia. Tauraco Press and Aves, Liége, Belgium.

6. Hiraldo, F., Veiga, J.P. \&Manez, M., 1990.Growth and nestling Black Kites Milvus migrans: effects of hatching order, weather and season. J. Zool. Lond.1990;222: 197-214.

7. Kennedy, R.S. \&Gozales, P.C., Dickinson, E.C., Miranda, Jr. H.C. \& Fisher, T.H., 2000.Black-winged or shouldered Kite (Elanuscaeruleus), A guide to the birds of the Philippines; Oxford University Press, USA, 2000; 08.

8. Klomp, H., 1970.The determination of clutch size in birds. A review. Ardea, 58: 1-124.

9. Koga, K., Siraishi, S. \& Uchida, T.A., 1989 Breeding ecology of the Black Kites Milvus migranslineatusin the 
Nagasaki Peniinsula, Kyushu. Jpn. J. Ornithol. 57: 57-66.

10. Kumar,A., 2001.Clay lumps as nest building material in kites. Newsletter for Birdwatchers, 41(3): 42.

11. Mayr, E. \& Cottrell, G.W., 1979. Checklist of the birds of the world. Volume 1. (Second edition). Camb, Mass, Mus. Comp. Zool.

12. Naoroji, R., 1997.A study on the breeding biology of resident raptors in Corbett National Park, Utter Pradesh. Journal Bombay Natural History Society, 94.

13. Ogada, D.L. \&Kibuthu, P.M., 2012.Breeding ecology of the Mackinder's Eagle-Owls (Bubo capensismackinderi) in farmlands of Central Kenya. J. Raptor Res. 46: 327335.
14. Olmos,F., 2003. Nest location, clutch size and nest success in the Scarlet Ibis Eudocimus rubber. Ibis. 145(online): E12-E18

15. Prakash, V., 1988. The General Ecology of Raptors (Families Accipitridae\&Strigidae, Class Aves) in Keoladeo National Park. Bharatpur. Unpublished thesis. Bombay Nat. Hist. Soc. Bombay University.

16. Skutch, A.F., 1949.Do tropical birds rear as many young as they can Nourish. Ibis.91: 430-458.

17. Skutch, A.F., 1954.Life histories of Central American Birds. Pacific Coast Avifauna.No-31.

18. Wells, D.R., 1999.The birds of the ThaiMalay Peinsula: Vol. 1 (NonPassarines)", Academic press. Identification, distribution map, habits, habitat, migration, conservation. 130132. 